\title{
SURVEY OF CHIRONOMIDAE (INSECTA: DIPTERA) FROM THE KUSKOKWIM RIVER WATERSHED IN WESTERN ALASKA
}

\author{
Barbara L. Hayford ${ }^{1}$, Robert L. Newell ${ }^{2}$, and Zach J. Crete 3
}

\begin{abstract}
Rapidly declining diversity of freshwater species necessitates surveys to document and describe patterns in biodiversity. To this end, a survey of Chironomidae (Insecta: Diptera) was conducted in a remote watershed of western Alaska. Larval chironomids were collected from 16 stream sites in the Kuskokwim River watershed in 2009 and 2010. Twenty-seven chironomid taxa were identified. Orthocladiinae was the most diverse subfamily and was numerically dominant at all sites except a glacial runoff stream where Diamesinae was numerically dominant. Two rare chironomids were collected in the study: an undescribed species of Stilocladius and a species of Orthocladius (Mesorthocladius). The latter genus has only 2 described species in North America, one in Ohio and one in Minnesota. Results of a nonmetric multidimensional scaling analysis indicated that sites varied based on changes in elevation, conductivity, $\mathrm{pH}$, and percent Diamesinae. Two high-elevation sites, one at the outflow of a lake and the other located along the glacial runoff stream, supported the most taxa in this study. Another lower-elevation springbrook also supported a relatively diverse assemblage of chironomids. Otherwise, diversity and richness was low at most sites. In Chironomidae, adults are often necessary for identification of many taxa to species, and so collection of adults should be a focus of future sampling of streams in western Alaska.
\end{abstract}

RESUMEn.-Debido a que la diversidad de algunas especies de agua dulce está disminuyendo con rapidez, es importante que se lleven a cabo estudios que documenten y describan los patrones de biodiversidad. Con este fin, se realizó un estudio sobre los Quironómidos (Insecta: Diptera) en una cuenca remota al oeste de Alaska. Se colectaron larvas de quironómidos de dieciséis arroyos en la cuenca del río Kuskokwim en los años 2009 y 2010. Se identificaron 27 taxa de quironómidos. Orthocladiinae fue la subfamilia con mayor diversidad y la más numerosa en todos los lugares, excepto en el caso de la escorrentía de un arroyo glacial, en el cual Diamesinae fue numéricamente la más dominante. Se colectaron dos quironómidos raros en el estudio: Orthocladius (Mesorthocladius) sp., que tiene sólo dos especies descritas en Norteamérica, una en Ohio y una en Minnesota; y una especie no descrita de Stilocladius. Los resultados de un análisis por escalamiento multidimensional no métrico indicaron que los sitios variaban por cambios de elevación, la conductividad, el pH y el porcentaje de Diamesinae. La mayor parte de los taxa de este estudio se concentraron en dos lugares con altas elevaciones, uno en la desembocadura de un lago y el otro, a lo largo de la escorrentía de un arroyo glacial. Algunos grupos con una relativa diversidad de taxa de quironómidos también se concentraron en otro arroyo de menor elevación. En los demás casos, la diversidad y la abundancia fueron bajas en la mayor parte de los lugares. Los Quironómidos adultos son necesarios para identificar muchos taxa a especie, por lo que en el futuro deberá de ser muy importante tomar muestras de arroyos ubicados en la parte oeste de Alaska.

Freshwater diversity is declining rapidly, with rates of species loss in freshwater fauna outpacing losses in terrestrial fauna (Strayer and Dudgeon 2010). Nonbiting midges or Chironomidae are a diverse and ubiquitous group of aquatic flies found in most types of aquatic habitat (Ferrington 2008). This family alone often comprises over $50 \%$ of macroinvertebrate fauna from freshwater ecosystems (Ferrington et al. 2008). Chironomidae play an important role in trophic interactions, particularly in diets of salmon (e.g., Loftus and Lenon 1977, Shreffler et al. 1992, Petrusso and Hayes 2001, Saiki et al. 2001), and are also important bioindicators of impact on aquatic ecosystems, even in relatively undisturbed regions (Rosenberg 1992, Raunio et al. 2011). The growing pressure from human activities on aquatic resources worldwide (Dudgeon et al. 2006) necessitates surveys to document and describe patterns in biodiversity. In addition, because Chironomidae are such an important part of aquatic ecosystems, surveys of Chironomidae will produce valuable information on overall diversity of freshwater macroinvertebrates (Raunio et al. 2011).

Streams in Alaska face pressures from human activities, such as mining (Milner and Piorkowski 2004), and now face increased degradation from climate change, including permafrost disruption (MacLean et al. 1999,

\footnotetext{
${ }^{1}$ Wayne State College, 1111 Main St., Wayne, NE 68787. E-mail: bahayfol@wsc.edu

${ }^{2}$ EcoServices Co., 2536 S. Dennis St. Kennewick, WA 99337.

${ }^{3}$ USFWS, Yukon Delta NWR, Box 346, Bethel, AK 99559.
} 
TABLE 1. Physical and chemical characteristics of study sites in the Kuskokwim River watershed, Alaska.

\begin{tabular}{|c|c|c|c|c|}
\hline Code & Site & Habitat type & Latitude & Longitude \\
\hline KISRP1 & Kisaralik River & Springbrook & $60^{\circ} 41^{\prime} 35.224^{\prime \prime} \mathrm{N}$ & $160^{\circ} 17^{\prime} 34.305^{\prime \prime} \mathrm{W}$ \\
\hline KISRP2 & Kisaralik River & Springbrook & $60^{\circ} 20^{\prime} 5.369^{\prime \prime} \mathrm{N}$ & $159^{\circ} 27^{\prime} 41.484^{\prime \prime} \mathrm{W}$ \\
\hline KISRP3 & Kisaralik River & Springbrook & $60^{\circ} 33^{\prime} 12.924^{\prime \prime} \mathrm{N}$ & $160^{\circ} 20^{\prime} 41.896^{\prime \prime} \mathrm{W}$ \\
\hline KISMC1 & Kisaralik River & Main channel & $60^{\circ} 19^{\prime} 57.229^{\prime \prime} \mathrm{N}$ & $159^{\circ} 26^{\prime} 43.147^{\prime \prime} \mathrm{W}$ \\
\hline KISMC2 & Kisaralik River & Main channel & $60^{\circ} 28^{\prime} 10.708^{\prime \prime} \mathrm{N}$ & $160^{\circ} 09^{\prime} 14.220^{\prime \prime} \mathrm{W}$ \\
\hline KISMC3 & Kisaralik River & Main channel & $60^{\circ} 45^{\prime} 41.681^{\prime \prime} \mathrm{N}$ & $160^{\circ} 35^{\prime} 46.304^{\prime \prime} \mathrm{W}$ \\
\hline KISMC4 & Kisaralik River & Main channel & $60^{\circ} 33^{\prime} 12.924^{\prime \prime} \mathrm{N}$ & $160^{\circ} 20^{\prime} 41.896^{\prime \prime} \mathrm{W}$ \\
\hline TUMC1 & Tuluksak River & Main channel & $60^{\circ} 57^{\prime} 24.307^{\prime \prime} \mathrm{N}$ & $160^{\circ} 15^{\prime} 41.526^{\prime \prime} \mathrm{W}$ \\
\hline TUMC2 & Tuluksak River & Main channel & $61^{\circ} 01^{\prime} 29.541^{\prime \prime} \mathrm{N}$ & $160^{\circ} 35^{\prime} 42.298^{\prime \prime} \mathrm{W}$ \\
\hline EKOUT & Eek River & Headwaters at lake outlet & $59^{\circ} 59^{\prime} 54.4^{\prime \prime} \mathrm{N}$ & $160^{\circ} 01^{\prime} 50.4^{\prime \prime} \mathrm{W}$ \\
\hline EKSB & Eek River & Springbrook & $60^{\circ} 08^{\prime} 34.7^{\prime \prime} \mathrm{N}$ & $160^{\circ} 15^{\prime} 18.8^{\prime \prime} \mathrm{W}$ \\
\hline EKMC1 & Eek River & Main channel & $60^{\circ} 08^{\prime} 34.7^{\prime \prime} \mathrm{N}$ & $160^{\circ} 15^{\prime} 18.8^{\prime \prime} \mathrm{W}$ \\
\hline EKMC2 & Eek River & Main channel & $60^{\circ} 00^{\prime} 10.7^{\prime \prime} \mathrm{N}$ & $160^{\circ} 03^{\prime} 01.9^{\prime \prime} \mathrm{W}$ \\
\hline GCEEK & Glacial Creek & Glacial tributary & $59^{\circ} 56^{\prime} 35.3^{\prime \prime} \mathrm{N}$ & $160^{\circ} 01^{\prime} 12.3^{\prime \prime} \mathrm{W}$ \\
\hline KISCR & Kisa Creek & Mountain tributary & $60^{\circ} 20^{\prime} 06.9^{\prime \prime} \mathrm{N}$ & $159^{\circ} 22^{\prime} 23.2^{\prime \prime} \mathrm{W}$ \\
\hline KWER & Kwethluk River & Springbrook & $60^{\circ} 19^{\prime} 48.281^{\prime \prime} \mathrm{N}$ & $161^{\circ} 2^{\prime} 47.026^{\prime \prime} \mathrm{W}$ \\
\hline
\end{tabular}

Walvoord and Striegl 2007). The purpose of this research was to (1) conduct a preliminary taxonomic survey of Chironomidae larvae from 16 sites on salmon spawning tributaries across an elevation gradient in the Kuskokwim River watershed in western Alaska and (2) relate variations in chironomid communities to water quality and environmental characteristics of sample sites. The Kuskokwim River watershed is an important fishing resource for regional tribes and commercial fisheries (Ebbin 2002) and is one of the longest free-flowing rivers in North America (Benke and Cushing 2011). The upper reaches of the Kuskokwim River watershed have been extensively mined in the past (Gray et al. 2000, Jewett et al. 2003), and thus this survey focused on sites to the south and east part of the water-shed, which had little to no mining. The watershed is bordered along the south and east by the Kuskokwim Mountains and is one of the more remote watersheds in Alaska, with few overland roads or trails connecting it to the interior. The remoteness of the high-elevation sites flowing from the Kuskokwim Mountains, combined with little to no disturbance along the southeastern portion of the watershed, means that this survey will make a valuable contribution to our basic understanding of historical communities of Chironomidae in southwestern Alaska.

\section{METHODS}

Covering 124,319 km², the Kuskokwim River watershed is one of the largest freely flowing watersheds in North America (Benke and Cushing 2011). Sixteen study sites located in the lower region of the Kuskokwim River watershed (known as the Kuskokwim Delta Basin) were each sampled one time during 2009 and 2010 (each site is known by a 4- or 5-character site code; Table 1; Fig. 1). The Kuskokwim River plain in the south central part of the basin where this study took place is characterized by fine silt and sand over fairly thick permafrost. Only one major town is found in the Kuskokwim River delta region, and use of the aquatic system is primarily commercial and native fishing (Ebbin 2002). The Eek, Kisaralik, and Kwethluk rivers, and to a lesser extent the Tuluksak River, all originate from these mountains. Willow was the dominant vegetation in the riparian zone at most sites. Some riparian zones were also characterized by communities of willow, cottonwood, and alder. Riparian zones along EKOUT, EKMC2, and GCEEK were characterized by tundra. Temperature, $\mathrm{pH}$, and conductivity were measured in situ using an Oakton PC-10 handheld unit. Equipment failure at 3 sites prevented measurement of these water quality variables. Five sites were springbrooks, 8 sites were along the main channel of the rivers, 2 sites were located along mountain tributaries, and one site was located along the headwater stream below a lake outlet (Table 1).

We collected larval chironomids from sampling sites by using a kick net with a mesh size of $250 \mu \mathrm{m}$, and we standardized collections by unit effort. Specimens were preserved in the field in $80 \%$ ethyl alcohol. Samples were examined in the field and preserved in 95\% ethyl alcohol. Mature larvae were prepared for identification in one of 2 ways. Following methods outlined in Beckett and Lewis (1982), 


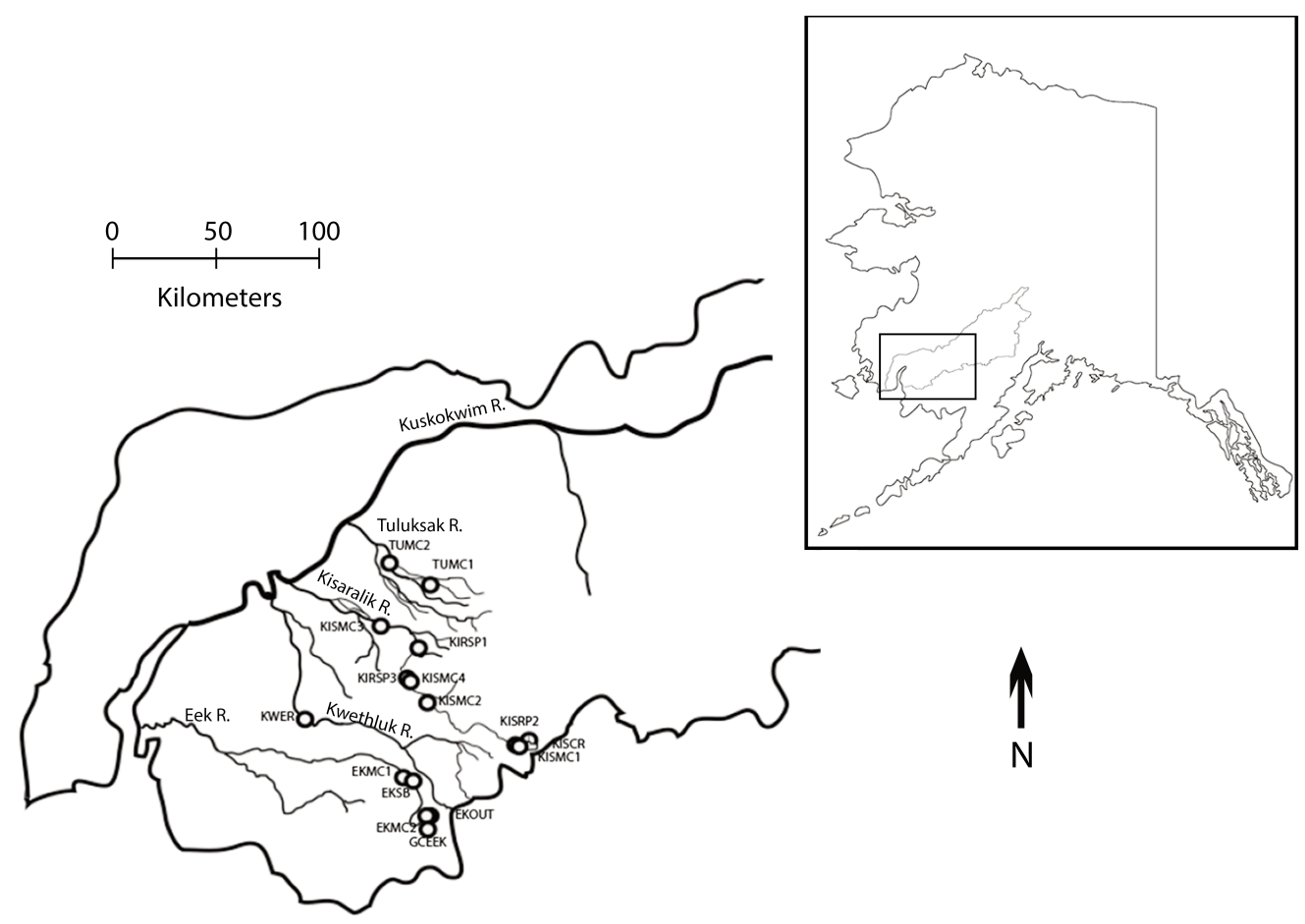

Fig. 1. Map of the lower Kuskokwim River watershed, Alaska. Sampling sites are denoted as open circles.

larvae were separated, when possible, into like organisms and placed on a slide in the mounting medium Euparol. After a day or two, the specimens were examined and aligned with the ventral surface facing up. A cover slip was added and the slide permitted to air dry. Larger or dark-colored specimens were placed in $10 \%$ $\mathrm{KOH}$ (potassium hydroxide) and heated at a low temperature for several minutes. The larvae were then transferred to glacial acetic acid to boil off the remaining tissues cleared by the $\mathrm{KOH}$ and to stop the $\mathrm{KOH}$ reaction. The larvae were then transferred to $95 \%$ ethyl alcohol and placed in Euparol as described above.

Mounted larvae were examined under compound microscopes and identified to subfamily, genus, or subgenus using identification keys in Wiederholm (1983), Ferrington et al. (2008), and Epler (2001). Some specimens could not be identified to genus and were retained at the next higher taxonomic level. For example, some Orthocladius are difficult to differentiate from Cricotopus, so these specimens were designated Orthocladius/Cricotopus and were considered ambiguous taxa. Estimates of richness were calculated based on unambiguous taxa such that ambiguous taxa were removed if they were redundant with higher-level taxa. Cuffney et al. (2007) showed that this process allows for retention of high-quality diversity data without biasing analyses with redundant data. Species were vouchered with either the Biodiversity Institute at the University of Kansas (Lawrence, KS) or the Museum of Natural History at Wayne State College (Wayne, NE).

Nonmetric multidimensional scaling (nmMDS) was used to visualize ordination of sites based on water quality data, environmental characteristics, Shannon-Wiener diversity, and relative richness of chironomid subfamilies. Relative richness of subfamilies was used to represent community assemblages in the analysis because of the extremely patchy nature of the individual taxonomic data. Three sites were removed from analysis due to missing water quality data. The resulting axes were then used as outcome variables in multiple regression analysis to determine which variables used in the nmMDS ordination were the strongest predictors of variation in the sites. All predictor and outcome variables met assumptions of normality and heteroscedasticity. A hierarchical 
TABLE 2. Taxon list and accession numbers for specimens collected in streams of the Kuskokwim River watershed, Alaska.

\begin{tabular}{|c|c|c|}
\hline Taxon & Institution holding vouchers & Accession number \\
\hline \multicolumn{3}{|l|}{ Tanypodinae } \\
\hline Ablabesmyia sp. & WSC & 2012.09.09.01 \\
\hline Thienemannimyia group & WSC & 2012.09.09.02 \\
\hline \multicolumn{3}{|l|}{ Diamesinae } \\
\hline Diamesa sp. & WSC & 2012.09.09.03 \\
\hline Pagastia sp. & WSC & 2012.09.09.04 \\
\hline Potthastia gaedii gr. sp. & WSC & 2012.09.09.05 \\
\hline \multicolumn{3}{|l|}{ Orthocladiinae } \\
\hline Corynocera sp. & WSC & 2012.09.09.06 \\
\hline Cricotopus (Cricotopus) spp. & WSC & 2012.09.09.07 \\
\hline Cricotopus (Isocladius) spp. & WSC & 2012.09.09.08 \\
\hline Diplocladius cultriger Kieffer, 1908 & KUBI & 739481 \\
\hline Eukiefferiella sp. & WSC & 2012.09.09.09 \\
\hline Heleniella sp. & WSC & 2012.09.09.10 \\
\hline Heterotrissocladius marcidus gr. sp. & KUBI & 739482 \\
\hline Krenosmittia sp. & WSC & 2012.09 .09 .11 \\
\hline Orthocladius (Eudactylocladius) sp. & WSC & 2012.09 .09 .12 \\
\hline Orthocladius (Euorthocladius) sp. & WSC & 2012.09 .09 .13 \\
\hline Orthocladius (Mesocladius) sp. & KUBI & 739478 \\
\hline Orthocladius (Orthocladius) sp. & WSC & 2012.09 .09 .14 \\
\hline Parametriocnemus sp. & WSC & 2012.09 .09 .15 \\
\hline Psectrocladius (Psectrocladius) sp. & WSC & 2012.09 .09 .16 \\
\hline Rheocricotopus sp. & KUBI & 739484 \\
\hline Stilocladius $\mathrm{n} . \mathrm{sp}$. & KUBI & 739485 \\
\hline Tvetnia sp. & WSC & 2012.09.09.17 \\
\hline \multicolumn{3}{|l|}{ Chironominae } \\
\hline Dicrotendipes sp. & WSC & 2012.09.09.18 \\
\hline Parachironomus sp. & WSC & 2012.09.09.19 \\
\hline Micropsectra spp. & WSC & 2012.09 .09 .20 \\
\hline Paratanytarsus sp. & WSC & 2012.09 .09 .21 \\
\hline Tanytarsus spp. & WSC & 2012.09 .09 .22 \\
\hline
\end{tabular}

model with forward switching was used to avoid highly correlated predictor variables. Significance was set at $P<0.05$, and statistical tests were performed using Number Cruncher statistical software (www.ncwebcenter.com).

\section{Results AND Discussion}

The survey resulted in a total of 27 taxa identified from 4 subfamilies of Chironomidae (Table 2). Orthocladiinae was the most diverse subfamily, represented by 18 taxa, and was followed by Chironominae, represented by 5 taxa (Table 2). Orthocladiinae were most diverse at all sites and were numerically dominant at all sites except for GCEEK, a glacial spring tributary of the Eek River (Table 1), where Diamesa sp. comprised $52 \%$ of specimens collected. Orthocladiinae commonly dominate diversity and abundance in north temperate streams; the subfamily becomes more common at higher latitudes and altitudes (Ashe et al. 1987) and was the only subfamily present at 10 of the study sites. Diamesa is commonly the dominant genus found in glacial melt streams and often the only genus of macroinvertebrate present at temperatures $<2{ }^{\circ} \mathrm{C}$ (Milner et al. 2001). Orthocladiinae and other Diamesinae are also present in glacial streams at temperatures $>2{ }^{\circ} \mathrm{C}$. Temperature in the glacial stream in this study was $7.1^{\circ} \mathrm{C}$. In that stream, Diamesa sp. and Orthocladius (Eudactylocladius) sp. were the dominant taxa representing the subfamilies Diamesinae and Orthocladiinae, but taxa representing the subfamilies Tanypodinae and Chironominae were also present.

Orthocladius (Mesorthocladius) sp. was found only at the springbrook on the Kwethluk River, where it comprised $57 \%$ of all specimens collected and was one of the most abundant species at any of the study sites. Larvae of $O$. (M.) lamellatus Sæther 2005 and O. (M.) frigidus (Zetterstedt 1838) both possess a unique character for species in Orthocladius, namely, the fine mouthpart structures called labral lamellae. No other larval characters are useful in differentiating between these 2 species as described by Sæther (2005). We cannot assign a species 
TABLE 3. Water quality and physical characteristics for study sites in the Kuskokwim River Watershed, Alaska. Values are used in the nmMDS ordination and multiple regression analysis.

\begin{tabular}{llcccr}
\hline Site code & $\mathrm{pH}$ & Conductivity $(\mu \mathrm{S})$ & Temperature $\left({ }^{\circ} \mathrm{C}\right)$ & Stream width $(\mathrm{m})$ & Elevation $(\mathrm{m})$ \\
\hline KISRP1 & 7.74 & 77.4 & 13.3 & 5.9 & 91 \\
KISRP2 & $\mathrm{n} / \mathrm{a}$ & $\mathrm{n} / \mathrm{a}$ & $\mathrm{n} / \mathrm{a}$ & 1 & 456 \\
KISRP3 & 8.12 & 113.1 & 12.3 & 5.6 & 167 \\
KISMC1 & $\mathrm{n} / \mathrm{a}$ & $\mathrm{n} / \mathrm{a}$ & $\mathrm{n} / \mathrm{a}$ & 26.27 & 458 \\
KISMC2 & $\mathrm{n} / \mathrm{a}$ & 108.4 & $\mathrm{n} / \mathrm{a}$ & 42.53 & 239 \\
KISMC3 & 7.93 & 110.1 & 10.8 & 34.77 & 46 \\
KISMC4 & 8.28 & 84.6 & 13.9 & 44.57 & 68 \\
TUMC1 & 8.19 & 80.7 & 9.5 & 29.99 & 15 \\
TUMC2 & 7.93 & 19.5 & 10.4 & 30.51 & 633 \\
EKOUT & 7.08 & 98.5 & 11.9 & 3.96 & 289 \\
EKSB & 7.76 & 98.5 & 9.3 & 23 & 289 \\
EKMC1 & 7.76 & 20.1 & 13.1 & 6.2 & 614 \\
EKMC2 & 7.07 & 15.53 & 7.1 & 5 & 482 \\
GCEEK & 7.88 & 112.6 & 7.1 & 4.22 & 76 \\
KISCR & 8.94 & 118.1 & 3.4 & & \\
KWER & 7.72 & & & & \\
\hline
\end{tabular}

epitaph to these specimens, but it is likely that the specimens belong to one of the 2 aforementioned species. Orthocladius (M.) frigidus has not been reported from Alaska, but it was reported as a winter-emerging chironomid in southeastern Minnesota streams (Anderson and Ferrington 2013) and has been recorded from northern Eastern Palaearctic streams (Hayford 2005, Makarchenko and Makarchenko 2011). The presence of this species in western Alaska may support the hypothesis of a Beringian link between east Palaearctic and west Nearctic populations similar to the putative biogeographical pattern for Nymphomyiidae (Courtney 1994). On the other hand, O. (M.) lamellatus is found in the Nearctic, primarily in headwater streams of Ohio. Orthocladius (Mesorthocladius) sp. in this study was collected in a small orthofluvial springbrook along the Kwethluk River. If $O$. (M.) lamellatus were present in Alaska, then populations in Ohio may be glacial relicts.

Like O. (M.) sp., Stilocladius was only present in the springbrook on Kwethluk River in this study. Stilocladius was represented by very small specimens that were initially difficult to separate from Parakiefferiella, but further study showed that the specimens have large lauterborn organs on the antennae, broad seta subdentalis on the mandible, and indication of setae under the broad ventromental plates characteristic of Stilocladius. The specimens also have apically toothed SI setae typical of S. montanus (Rossaro 1979) and S. orientalis (Makarchenko and Makarchenko 2003), and the short apical tooth of the mandible of $S$. orientalis.
However, the Alaska specimens also have distinctly bifid premandibles, indicating that the Stilocladius at Kwethluk River does not fit within the currently described species and is either a new species or a Nearctic species of Stilocladius that lacks a description for the larval stage. All other Stilocladius species have premandibles with a single simple tooth, although larvae of S. intermedius Wang 1998 and S. kurobekeyakius (Sasa and Okazawa 1992, redescribed in Yamamoto 1996) have not been described. Future collections along the Kwethluk River should include adult Chironomidae so that the life stages of this new species can be associated and the species described.

Water quality and physical variables varied considerably across sites (Table 3). In particular, elevation ranged from 15 to $666 \mathrm{~m}$; stream width ranged from $1 \mathrm{~m}$ to over $42 \mathrm{~m}$; and conductivity was low and ranged from 15.53 to $118.1 \mu \mathrm{S}$ (Table 3). Stream pH was neutral to slightly basic, and conductivity was low for most sites. Temperatures ranged from 3.4 to $14.9^{\circ} \mathrm{C}$ and were not correlated to changes in elevation and did not consistently relate to water origins (e.g., groundwater or glacial meltwater). Diversity, richness, and relative richness of chironomid subfamilies also varied across sites, with highest diversity and richness at EKOUT (Table 4). In the ordination, sample sites clearly separated based on variation in water quality and physical variables and in richness estimates (Fig. 2). Based on multiple regression analysis, elevation, conductivity, and water temperature were significantly correlated with axis 1 , and percent Diamesinae, 
TABLE 4. Relative abundance, Shannon-Wiener diversity index $\left(H^{\prime}\right)$, richness $(S)$, and relative richness for subfamilies of Chironomidae from the Kuskokwim River watershed, Alaska. Values are used in the nmMDS ordination and multiple regression analysis. Subfamilies: Tanypodinae (TANY), Diamesinae (DIAM), Orthocladiinae (ORTH), Chironominae (CHIR).

\begin{tabular}{|c|c|c|c|c|c|c|}
\hline \multirow[b]{2}{*}{ Site code } & \multicolumn{2}{|c|}{ Diversity measures } & \multicolumn{4}{|c|}{$\begin{array}{l}\text { Relative richness given as \% subfamily } \\
\text { (number of taxa per subfamily) }\end{array}$} \\
\hline & $H^{\prime}$ & $S$ & TANY\% (2) & DIAM\% (3) & ORTH\% (17) & CHIR\% (5) \\
\hline KISRP1 & 0 & 1 & 0 & 0 & 100 & 0 \\
\hline KISRP2 & 0.64 & 1 & 0 & 0 & 100 & 0 \\
\hline KISRP3 & 1.08 & 3 & 0 & 33 & 67 & 0 \\
\hline KISMC1 & 1.55 & 4 & 0 & 25 & 75 & 0 \\
\hline KISMC2 & 1.92 & 7 & 0 & 29 & 71 & 0 \\
\hline KISMC3 & 1.30 & 3 & 0 & 0 & 100 & 0 \\
\hline KISMC4 & 1.00 & 2 & 0 & 0 & 100 & 0 \\
\hline TUMC1 & 0 & 1 & 0 & 0 & 100 & 0 \\
\hline TUMC2 & 0 & 1 & 0 & 0 & 100 & 0 \\
\hline EKOUT & 2.39 & 18 & 11 & 11 & 50 & 28 \\
\hline EKSB & 0 & 1 & 0 & 0 & 100 & 0 \\
\hline EKMC1 & 0 & 1 & 0 & 0 & 100 & 0 \\
\hline EKMC2 & 0 & 1 & 0 & 0 & 100 & 0 \\
\hline GCEEK & 1.97 & 9 & 11 & 22 & 67 & 0 \\
\hline KISCR & 0.97 & 2 & 0 & 0 & 100 & 0 \\
\hline KWER & 1.49 & 11 & 0 & 9 & 82 & 9 \\
\hline
\end{tabular}

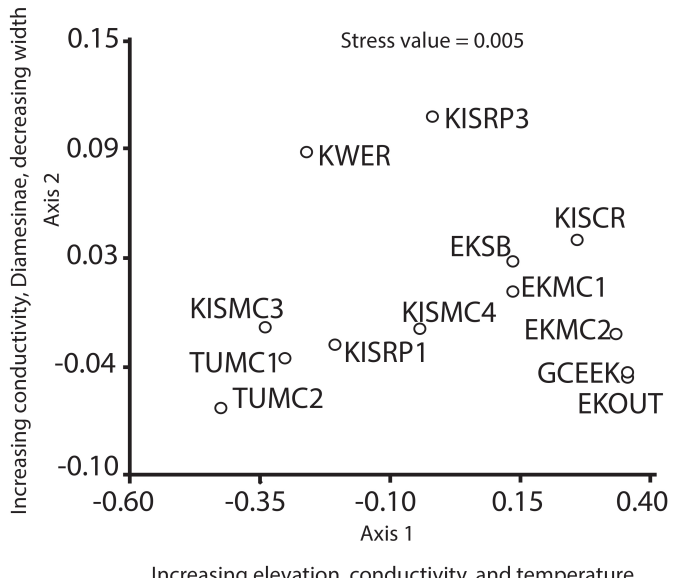

Fig. 2. Nonmetric multidimensional scaling map comparing sites based on physical, water quality, and diversity variables. Open circles denote sampling sites. Statistically significant predicators of variation along the axes are given for each axis. See Table 5 for complete results of the multiple regression analysis.

conductivity, and stream width were significantly correlated with axis 2 (Table 5; Fig. 2). The headwaters of the Eek River (EKOUT) and the glacial tributary stream (GCEEK) formed a cluster in the ordination that reflected increases in elevation and conductivity, as well as increase in Diamesinae (Fig. 2). EKOUT supported the most species (18), likely due to the additive taxa from both the lake and the outflow stream. Hayford et al. (2006) showed that chironomid assemblages were distinctly different between a lake and inflowing streams in Mongolia, but these habitats were separated by sand, gravel, or cobble bars. When such habitats are contiguous, it is possible that the mixture of assemblages increases diversity. For example, Willis and Magnuson (2000) showed that lake-stream ecotones support a greater diversity of fish than either ecosystem does individually. The other site of this small cluster, GCEEK, supported 9 species. Glacial streams have low diversity dominated by Diamesinae (Milner et al. 2001), but diversity may increase as a function of distance from the glacier, because groups like Orthocladiinae show up in samples (LodsCrozet et al. 2001).

Elevation was a strong and significant predictor of variation along axis 1 , and low elevation was one variable responsible for isolating KWER from other sites (Fig. 2), confirming that this site is unique. This springbrook supported 11 species, including Orthocladius (Mesocricotopus) sp. and Stilocladius sp. mentioned above. Diverse communities of Chironomidae are known from cold spring environments (Lindegaard 1995, Ferrington 1998). Cold springs typically exhibit less temperature variation than do nearby streams dominated by surface flow and affected by fluctuations in 
TABLE 5. Regression correlations from the multiple regression analysis of nmMDS axis coordinates and environmental and taxonomic predictors.

\begin{tabular}{lcccc}
\hline & Elevation & Conductivity & Temperature & Stream width \\
\hline Axis 1 , Model $\mathrm{R}=0.94^{* *}$ & $0.54^{* *}$ & $0.05^{* *}$ & $0.02^{*}$ & 0.01 \\
\cline { 2 - 5 } \% & DIAM & Conductivity & Stream width & Elevation \\
\cline { 2 - 5 } Axis 2, Model $\mathrm{R}=0.89^{* *}$ & $0.10^{*}$ & $0.46^{* *}$ & $0.12^{*}$ & 0.03 \\
\hline
\end{tabular}

*Significant at $0.01 \leq P \leq 0.05$

*** Signficant at $P \leq 0.01$

ambient air temperatures (McCabe 1998). Thus, cold springs can act as stable thermal refugia and may support more species than nearby streams subjected to the large variation in temperature in the subarctic environment of the Kuskokwim watershed. Furthermore, cold springbrooks feed into the salmon tributaries in the region. The connectivity between springbrooks and the salmon tributaries makes it likely that cold spring Chironomidae contribute to the overall energy of salmon food webs in the lower Kuskokwim River watershed.

\section{ACKNOWLEDGMENTS}

We thank the U.S. Fish and Wildlife Service and Dan Gillikin and Tom Doolittle for their support and assistance in this research. Part of this research was done under the auspices of the Central Plains Center for Bioassessment, Lawrence, Kansas. Voucher specimens are stored at the University of Kansas Biodiversity Institute and at the Natural History Museum at Wayne State College, Nebraska.

\section{Literature Cited}

Anderson, A.M., AND L.C. Ferrington JR. 2013. Resistance and resilience of winter-emerging Chironomidae (Diptera) to a flood event: implications for Minnesota trout streams. Hydrobiologia 707:59-71.

Ashe, P., D.A. Murray, and F. Reiss. 1987. The zoogeographic distribution of Chironomidae (Insecta: Diptera). Annales de Limnologie 23(1):27-60.

BecketT, D.C., AND P.A. Lewis. 1982. An efficient procedure for slide mounting of larval Chironomidae. Trans-actions of the American Microscopical Society 101(1):96-99.

Benke, A.C., And C.E. Cushing. 2011. Background and approach. Pages 1-18 in A.C. Benke and C.E. Cushing, editors, Rivers of North America. Academic Press.

Courtney, G.W. 1994. Biosystematics of the Nymphomyiidae (Insecta: Diptera): life history, morphology, and phylogenetic relationships. Smithsonian Contributions to Zoology 550:1-41.

Cuffney, T.F., M.D. Bilger, and A.M. Haigler. 2007. Ambiguous taxa: effects on the characterization and interpretation of invertebrate assemblages. Freshwater Science 26:286-307.

Dudgeon, D., A.H. Arthington, M.O. Gessner, Z.-I. Kawabata, D.J. Knowler, C. Lévêque, R.J. Naiman, A.H. Prieur-Richard, D. Soto, M.L.J. Stiassny, AND C.A. Sullivan. 2006. Freshwater biodiversity: importance, threats, status and conservation challenges. Biological Reviews 81:163-182.

EbBin, S.A. 2002. What's up? The transformation of upstream-downstream relationships on Alaska's Kuskokwim River. Polar Geography 26:147-166.

EpLer, J.H. 2001. Identification manual for the larval Chironomidae (Diptera) of North and South Carolina: a guide to the taxonomy of the midges of the southeastern United States, including Florida. St. Johns River Water Management District, FL.

Ferrington, L.C., JR. 1998. Generic composition of the chironomid fauna in springs of North America. Pages 141-155 in L. Botosaneanu, editor, Studies in crenobiology: the biology of springs and springbrooks. Backhuys Publishers, Leiden, The Netherlands.

2008. Global biodiversity of non-biting midges (Chironomidae: Diptera) in freshwater. Hydrobiologia 595:447-455.

Ferrington, L.C., Jr., M.B. Berg, and W.P. Coffman. 2008. Chironomidae. Pages 847-989 in R.W. Merritt, K.W. Cummins, and M.B. Berg, editors, An introduction to the aquatic insects of North America. 4th edition. Kendall/Hunt Publishing Co., Dubuque, IA.

Gray, J.E., P.M. Theodorakos, E.A. Bailey, and R.R. TURnER. 2000. Distribution, speciation, and transport of mercury in stream-sediment, stream-water, and fish collected near abandoned mercury mines in southwestern Alaska, USA. Science of the Total Environment 260:21-33.

Hayford, B.L. 2005. New records of Chironomidae (Insecta: Diptera) from Mongolia with review of distribution and biogeography of Mongolian Chironomidae. Journal of the Kansas Entomological Society 78:89-99.

HaYFord, B., J. BaChMANN, AND M. GOTOV. 2006. A comparison between communities of Chironomidae (Insecta: Diptera) from lake bays and affluent streams of the Lake Hovsgol watershed, Mongolia. Proceedings of the Academy of Natural Sciences of Philadelphia 155:13-23.

Jewett, S.C., X. Zhang, A. Sathy Naidu, J.J. Kelley, D. DASHER, AND L.K. DUfFy. 2003. Comparison of mercury and methylmercury in northern pike and Arctic grayling from western Alaska rivers. Chemosphere 50:383-392.

Kieffer, J.J., and A. Thienemann. 1908. Neue und bekannte Chironomiden und ihre Metamorphose. I. Neue und bekannte Chironomiden [Kieffer, J.J.]. 
II. Chironomidenmetamorphosen [Thienemann, A.]. Zeitschrift für Wissenschaftliche Insekten Biologie 4:1-10, 33-39, 78-84, 124-128, 184-190, 214-219, 256-259, 277-286.

LindegaARd, C. 1995. Chironomidae (Diptera) of European cold springs and factors influencing their distribution. Journal of the Kansas Entomological Society 68:108-131.

Lods-Crozet, B., V. LenCioni, J.S. ÓlafsSon, D.L. SNOOK, G. Velle, J.E. Brittain, E. Castella, and B. RossARO. 2001. Chironomid (Diptera: Chironomidae) communities in six European glacier-fed streams. Freshwater Biology 46:1791-1809.

Loftus, W.F., AND H.L. LENON. 1977. Food habits of the salmon smolts Oncorhynchus tshawytscha and $O$. nerka, from the Salcha River, Alaska. Transactions of the American Fisheries Society 106:235-240.

MacLean, R., M.W. Oswood, J.G. Irons III, and W.H. MCDOWELL. 1999. The effect of permafrost on stream biogeochemistry: a case study of two streams in the Alaskan (USA) taiga. Biogeochemistry 47:239-267.

MaKarchenKo, E.A., AND M.A. MaKarChEnKo. 2003. A new and little known species of Stilocladius Rossaro, 1979 (Diptera, Chironomidae, Orthocladiinae) from the Russian Far East. Eurasian Entomological Journal 2:135-140.

2011. Fauna and distribution of the Orthocladiinae of the Russian Far East. Pages 107-205 in X. Wang and W. Liu, editors, Contemporary chironomid studies - Proceedings of the 17th International Symposium on Chironomidae (July 6-9, 2009 Nankai University, China). Nankai University Press, China.

MCCABE, D.J. 1998. Biological communities in springbrooks. Pages 221-228 in L. Botosaneanu, editor, Studies in crenobiology: the biology of springs and springbrooks. Backhuys Publishers, Leiden, The Netherlands.

Milner, A.M., J.E. Brittain, E. Castella, and G.E. PETTS. 2001. Trends of macroinvertebrate community structure in glacier-fed rivers in relation to environmental conditions: a synthesis. Freshwater Biology 46:1833-1847.

Milner, A.M., AND R.J. Pionkowski. 2004. Macroinvertebrate assemblages in streams of interior Alaska following alluvial gold mining. River Research and Applications 20:719-731.

Petrusso, P., And D.B. Hayes. 2001. Invertebrate drift and feeding habits of juvenile chinook salmon in the upper Sacramento River, California. California Fish and Game 87(1):1-18.

Raunio, J., J. Heino, and L. Paasivirta. 2011. Non-biting midges in biodiversity conservation and environmental assessment: findings from boreal freshwater ecosystems. Ecological Indicators 11:1057-1064.

RosenberG, D.M. 1992. Freshwater biomonitoring and Chironomidae. Netherland Journal of Aquatic Ecology 26:101-122.
Rossaro, B. 1979. Stilocladius montanus n. gen. n. sp.: descrizione di un nuovo genere e di una nuova specie di Orthocladiinae delle Alpi Italiane (Diptera, Chironomidae). Bollettino del Museo Civico di Storia Naturale di Verona 6:347-352.

SÆTHER, O.A. 2005. A new subgenus and new species of Orthocladius van der Wulp, with a phylogenetic evaluation of the validity of the subgenera of the genus (Diptera: Chironomidae). Zootaxa 974:1-56.

Saiki, M.K., B.A. Martin, L.D. Thompson, and D. Welsh. 2001. Copper, cadmium, and zinc concentrations in juvenile Chinook Salmon and selected fish-forage organisms (aquatic insects) in the Upper Sacramento River, California. Water, Air, and Soil Pollution 132: 127-139.

Sasa, M., AND T. OKaZaWa. 1992. Studies on the chironomid midges (yusurika) of Toga Mura, Toyama. Part 2. The subfamily Orthocladiinae. Part 2. The subfamily Orthocladiinae Res. Rep. Toyama Prefect. Environmental Pollution Research Center 1992:92-204.

Shreffler, D.K., C.A. Simenstad, and R.M. Thom. 1992. Foraging by juvenile salmon in a restored estuarine wetland. Estuaries 15:204-213.

Strayer, D.L., And D. Dudgeon. 2010. Freshwater biodiversity conservation: recent progress and future challenges. Journal of the North American Benthological Society 29:344-358.

WANG, X. 1998. Description of a new species of Stilocladius from China (Diptera, Chironomidae). Studia Dipterologica 5:81-83.

Walvoord, M.A., and R.G. StriegL. 2007. Increased groundwater to stream discharge from permafrost thawing in the Yukon River basin: potential impacts on lateral export of carbon and nitrogen. Geophysical Research Letters 34:L12402, http://dx.doi.org /10.1029/2007GL030216

Wiederholm, T., editor. 1983. Chironomidae of the Holarctic Region, keys and diagnoses, Part 1. Larvae. Entomologica Scandinavica, Supplement No. 19.

Willis, T.V. and J.J. Magnuson. 2000. Patterns in fish species composition across the interface between streams and lakes. Canadian Journal of Fisheries and Aquatic Sciences 57:1042-1052.

Yамамото, M. 1996. Redescription of a small chironomid midge Stilocladius kurobekeyakius (Sasa \& Okazawa, 1992) transferred from Eukiefferiella (Diptera, Chironomidae). Japanese Journal of Entomology 64: 729-732.

Zetterstedt, J.W. 1838. Sectio tertia. Diptera Dipterologis scandinaviae amices et popularibus carissimus. Pages 477-868 in Insecta Lapponica. Leipzig. VI + $1140 \mathrm{pp}$.

Received 28 June 2013 Accepted 20 December 2013 